\title{
УДК 9
}

DOI $10.21661 / \mathrm{r}-467279$

\section{И.Е. Новикова}

\section{РЕФОРМА 1861 ГОДА НА СТАВРОПОЛЬЕ}

Аннотация: данная статья посвящена анализу сочиоэкономических особенностей проведения крестьянской реформы на Ставрополье, главная из которых заключалась в достаточно низкой плотности заселения региона и численности крепостных крестьян. Работа включает в себя рассмотрение положений одного из самых ранних проектов освобождения крестьян, созданный крупнейшими помещиками Пятигорского уезда братьями Калонтаровыми. В данной статье использованы материаль Государственного архива Ставропольского края.

Ключевые слова: реформа, Пятигорский уезд, проект освобождения, помещики Калонтаровы.

\section{I.Y. Novikova}

\section{THE REFORM OF 1861 IN STAVROPOL}

Abstract: this article is devoted to analysis of the socioeconomic features of the peasant reform in the Stavropol region, the main of which was sufficiently low density settlement in the region and the number of serfs. The work includes consideration of the provisions of one of the earliest projects of emancipation of the serfs, created by the largest landowners of the County Pyatigorsk by the Kalantarovs' brothers. The materials in this article are used from the State archive of the Stavropol territory.

Keywords: reform, Pyatigorsk district, a project of liberation, landowners the Kalontarovs.

Освоение Северного Кавказа невозможно представить без учета тех экономических и социальных сдвигов, которые произошли в результате отмены крепостного права. Страна в момент проведения реформ начинает жить более 
интенсивно, насыщенно, время как бы уплотняется, особенно остро обнажаются все противоречие, которые в результате реформ находят то или иное разрешение. Поэтому реформаторский отрезок истории представляет для нас особый интерес. Что же такое реформа? В чем ее отличие от революции, которая также является одним из видов разрешения общественных противоречий? Существуем множество определений этих процессов, но визуально сущность реформы и революции я бы представила следующим образом: перед вами веревка, в виде которой мы можем вообразить цепь исторических событий, приведших к накоплению противоречий. Если мы узел противоречий разрежем, то получим революцию, которая прерывает логику предшествующего развития общества, как системы и начинает выстраивать новую систему. Если же мы будем развязывать узел, проводя реформы, то мы сохраним преемственность общественного опыта, накопленного ранее живущими поколениями, не сломаем структуру реформируемой системы, а выведем ее на качественно новый уровень. Таким образом, реформа - необходимая корректировка, дающая возможность обществу сохранить традиции, культуру и использовать их дальше в новых условиях, развивая и обогащая общественный опыт, находя компромисс между опытом и новыми идеями. Я развяжу наш узел, поскольку мы будем говорить о реформаторском пути развития нашего региона в 19 веке.

Крестьянская реформа на Ставрополье имела целый ряд социоэкономических особенностей, главная из которых заключалась в достаточно низкой плотности заселения региона, что видно из следующей таблицы, составленной на основании данных Государственного архива Ставропольского края (таблица 1).

Данные таблицы обращают наше внимание на две особенности - низкую плотность населения вообще (она составила 4, 8 человек на квадратную версту), и низкую численность дворянского сословия в округе накануне реформы. Для сравнения, в тот же период времени плотность населения Звенигородского уезда Московской губернии составляла 41,9 человек на квадратную версту. Накануне реформы 1861года помещичьи имения были сосредоточены 
преимущественно в Пятигорском уезде. Помещичье землевладение в губернии не получило широкого распространения. В 1861 году в губернии насчитывалось лишь 49 имений дворян. Для сравнения, в Тверской губернии накануне реформы насчитывалось более 4000 дворянских именийв которых числилось 7942 души крепостных мужского пола [2, с. 89]. Ставропольским помещикам принадлежало 191541 десятина земли, что составляло всего 2,3\% от общей площади земли в губернии. По уездам земли и крестьяне распределились следующим образом: (таблица 2).

Все наиболее крупные поместья располагались в Пятигорском уезде: имение братьев Калонтаровых в с. Маслов кут, имение Ребровых в с. Владимировка [3, с. 37]. Первое место по числу крепостных принадлежало Пятигорскому уезду, где к 1859 году было сосредоточено 74\% крепостных. На основании данных таблицы мы делаем вывод о том, что Ставропольские помещики по преимуществу были мелкими не столько по размеру земельных владений, сколько по количеству крепостных крестьян. Удобной земли во владении помещиков было 191541 десятина. Если разделить количество помещичьей земли в Ставропольском уезде на количество крепостных, то мы увидим, что каждый крепостной должен так или иначе обработать 102 десятины. В центральных губерниях по итогам реформы 1861года крестьянские наделы составили 3.3 десятины на душу. Таким образом, очевидна необходимость освоения огромных, по сравнению с центром страны, земельных угодий Ставрополья. Мы можем определить Пятигорский уезд как наиболее нуждающийся и заинтересованный в проведении крестьянской реформы. Косвенно это вывод могут подтвердить данные о ценности поземельных угодий в губернии накануне реформы [Таблица 3].

Возможно, поэтому в пятигорском уезде раньше и острее, чем в других уездах губернии, встал крестьянский вопрос. Именно в Пятигорском уезде, в имении братьев Гавриила и Герасима Калонтаровых произошли крестьянские восстания, вопрос об этих волнениях 28 января 1858 года был доложен самому императору [1, ГАСК, ф.1279, оп. 1, д. 1]. Император, хотя и согласился с тем, 
что больше в возмущении крестьян виновны местные власти (причина-плохое административное управление), тем не менее, зачинщиков надо наказать в установленном порядке. Император выразил мнение, что оставлять имение в помещичьем владении нецелесообразно, так как «... по присущему простолюдинам невежественному упрямству, будет продолжаться нескончаемая борьба...» [1, ГАСК, ф. 1279, оп. 1, д. 1].Поэтому Император повелел склонить братьев к уступке имения казне. Калонтаровы, чистосердечно желая подчиниться императорской воле, оставив за собою все земли с угодьями, изъявили готовность на отчуждение от себя всех маслокутских крестьян, отпустив их в свободное состояние, в чем и дали подписку. В результате этого конфликта между крестьянами и помещиками родился первый в губернии и один из самых ранних в России проект освобождения крестьян, подписанный в 1858 году братьями Калонтаровыми. Положения этого проекта представляют немалый интерес. За свое освобождение все крестьяне мужского пола старше 18 лет обязаны внести 300 рублей серебром, в возрасте до 10 лет- половину суммы. Крестьянки до 16 лет освобождались за 70 рублей, в возрасте до 10 лет - за 35 рублей [1, ГАСК, ф.1279, оп. 1 д. 1]. В этих выкупных сумма просматривается половая дискриминация, вызванная реалиями патриархального общества. Стоимость свободы мужчины приравнивалась к стоимости четырех коней, которые в 1858 году стоили до 70 рублей. Выкуп мужчины был в 4 раза выше, чем выкуп женщины. По положениям проекта Калонтаровых, престарелые свыше 60 лет и увечные освобождались без выкупа. Взнос распределялся на 5 лет, мог заменяться «работаю, произведениями и другими средствами» [1, ГАСК, ф.1279, оп. 1, д. 1]. Можно было платить и дольше, но не более 12 лет. По взносу платы все семейство крестьян освобождается вместе, но не порознь. Выкуп за годовалых детей составлял 6 рублей. Таким образом, принимая во внимание многочисленность крестьянских семей и одномоментность внесения суммы выкупа можно сделать вывод о тяжелых в финансовом отношении для крестьян условиях освобождения. Тем более, что по проекту Калонтаровых, во время переходного периода обязанности крестьян в отношении помещиков 
оставались прежними, так как они будут продолжать пользоваться помещичьей землей и угодьями. Значит, времени и сил для отходничества с целью заработать на выкуп у крестьян фактически не оставалось. Однако, сама сумма выкупа, в сравнении с суммами, назначенными позднее по Положению 1861 года для нечерноземных губерний не может считаться высокой так как в нашем регионе основную ценность представляла земля, без которой крестьяне и освобождались по проекту Калонтаровых. Крестьянин, получивший по этому проекту вольную имел право брать с собой только движимое имущество: скот, земледельческие орудия, утварь, домашнюю принадлежность. Но недвижимое имущество - избы, сады, виноградники остаются в распоряжении помещика. То есть, крестьяне, оторванные от основного средства производства - земли вынуждены бы были искать новые средства к существованию и это. В первую очередь, дало бы свободные рабочие руки для развития промышленности губернии. Социальная ситуация, которая сложилась бы, если бы проект был осуществлен, по своей обостренности очень напоминает ситуацию, сложившуюся в Англии в результате процесса огораживания. Иначе говоря, проект Калонтаровых можно рассматривать как проект быстрого буржуазного переустройства общества. Но скорость вообще не свойственна русской истории, несла в себе тяжелую болезненность для крестьян, лишенных в одночасье привычных реалий и жизненных ориентиров и не знающих, что делать со своей свободой. Видимо, Калонтаровы, разрабатывая свой проект, питали надежды что освободятся лишь самые отчаянные, мыслящие по- новому крепостные. А они - то, как раз и менее всего желательны в имении, как возможные возмутители порядка. В проекте присутствуют и некоторые намеки на юридическую защищенность остающихся и временно обязанных крестьян. Так, они не могут быть наказаны без решения суда [1, ГАСК, ф. 1279, оп. 1, д. 1]. На мой взгляд, удивительно передовая и смелая мысль для помещиков-крепостников. Какова же была реакция правительства на этот проект?На основании того, что Казначейство, не имея никакой выгоды, понесет от этого дела одни убытки, условия проекта были отвергнуты. Император предлагает еще 
раз склонить помещиков к продаже имения в казну, считая это наилучшим выходом и гарантией от беспорядков. Интересно указание, что «...дело это должно быть решено без всякой огласки» [1, ГАСК, ф.1279, оп. 1, д. 1]. Вот в этой фразе, по-моему, и заключен ключ к отказу правительства. Через чур смелые планы братьев Калонтаровых могли вызвать целую социальную бурю в накаленной до предела обстановке русской деревни. Работа над проектом освобождения крестьян только начиналась. Первое совещание дворянства по крестьянскому вопросу состоялось 29 мая 1858 года в Доме Дворянских депутатских собраний под председательством дворянского предводителя полковника Капакова после многочисленных отговорок и отписок вышестоящему начальству. На этом заседании присутствовало всего 15 дворян. Столь низкая заинтересованность дворян в работе комитета еще раз указывает на одну из особенностей социально-экономического развития губернии - почти полное отсутствие крупного дворянства, кровно заинтересованного в отстаивании своих интересов при проведении реформы.

Эти особенности были отмечены и в предписании правительства губернскому дворянскому комитету. В предписании говорилось: «...В связи с обширностью земель и немногочисленностью населения в Ставропольской губернии еще не существует усадебной оседлости крестьян в полном объеме. Значит, можно будет предоставить помещикам и крестьянам право по обоюдному согласию определить количество земли, отдаваемой крестьянам и для усадебной оседлости, и для других потребностей, а также назначение за то оброка, работы и даже самой цены выкупа...» [1, ГАСК, Ф.1279, д. 1, оп. 1]. Выводы правительства совпадают с выводами, которые сделаны нами на основании анализа статистических данных.

Как видно из этого предписания, благодаря особенностям своего развития, губерния получила чуть ли не полную свободу в проведении неизбежной и необходимой России, как воздух, крестьянской реформы. 
Сочиальньй состав народонаселения Ставропольского округа в 1860 г. Площадь округа - 6756 квадратных верст [ГАСК, Ф. 1279, оп. 1, д. 1]

\begin{tabular}{|c|c|c|c|c|c|c|}
\hline Дворян & Купцов & Мещан & $\begin{array}{c}\text { Отставных } \\
\text { нижних } \\
\text { чинов }\end{array}$ & Контанистов & $\begin{array}{c}\text { Мещан } \\
\text { духовного } \\
\text { звания }\end{array}$ & Крестьян \\
\hline \multicolumn{7}{|c|}{ Медвежинская волость } \\
\hline 5 & 10 & 25 & 66 & 12 & 32 & 8553 \\
\hline \multicolumn{7}{|c|}{ Пелагиадская волость } \\
\hline- & - & - & 117 & 87 & 58 & 11189 \\
\hline \multicolumn{7}{|c|}{ Песганокопская волость } \\
\hline 7 & 23 & 45 & 40 & - & 86 & 15159 \\
\hline \multicolumn{7}{|c|}{ Петровская волость } \\
\hline- & 44 & 51 & 38 & - & 35 & 7423 \\
\hline 12 & 77 & 211 & 183 & 99 & 121 & 32324 \\
\hline \multicolumn{7}{|c|}{ Итого 33015 человек } \\
\hline
\end{tabular}

Таблица 2

Распределение помещичьей земли и крепостных крестьян в Ставропольской губернии накануне крестьянской реформы [ГАСК, Ф. 1279, оп. 1 д. 1]

\begin{tabular}{|c|c|c|}
\hline Уезды & Земли & Крепостные крестьяне \\
\hline Ставропольский & 30010 дес. & 292 \\
\hline Пятигорский & 98641 дес. & 5450 \\
\hline Моздокский & 9248 дес. & 161 \\
\hline Кизлярский & 53642 дес. & 1445 \\
\hline Итого & 191541 дес. & 7348 \\
\hline
\end{tabular}

Таблица 3

Ценность поземельных угодий в Ставропольской губернии накануне крестьянской реформы 1861года [ГАСК, Ф. 1279, оп. 1 д. 1]

\begin{tabular}{|l|c|c|c|c|c|c|}
\hline \multicolumn{4}{|c|}{ Продажная цена за десятину } & \multicolumn{3}{|c|}{ Наемная цена за десятину } \\
\hline Уезды & $\begin{array}{c}\text { Заселенная } \\
\text { земля }\end{array}$ & $\begin{array}{c}\text { Незаселен- } \\
\text { ная } \\
\text { земля }\end{array}$ & Леса & $\begin{array}{c}\text { Огородная } \\
\text { земля }\end{array}$ & Пашня & Сенокосы \\
\hline $\begin{array}{l}\text { Ставрополь- } \\
\text { ский }\end{array}$ & $33 \mathrm{p}$. & $16 \mathrm{p}$. & $250 \mathrm{p}$. & $18 \mathrm{p}$. & $10 \mathrm{p}$. & $6 \mathrm{p}$. \\
\hline Пятигорский & $35 \mathrm{p}$. & $17 \mathrm{p}$. & $300 \mathrm{p}$. & $20 \mathrm{p}$. & $12 \mathrm{p}$. & $7 \mathrm{p}$. \\
\hline
\end{tabular}




\begin{tabular}{|l|c|c|c|c|c|c|}
\hline Кизлярский & $31 \mathrm{p}$. & $15 \mathrm{p}$. & $126 \mathrm{p}$. & $22 \mathrm{p}$. & $11 \mathrm{p}$. & $5 \mathrm{p}$. \\
\hline По губернии & $33 \mathrm{p}$. & $16 \mathrm{p}$. & $225 \mathrm{p}$. & $20 \mathrm{p}$. & $11 \mathrm{p}$. & $6 \mathrm{p}$. \\
\hline & & & & & & \\
\hline
\end{tabular}

\section{Список литературы}

1. ГАСК, Ф. 1279, оп. 1, д. 1

2. Крикунов В.П. Крестьянская реформа 1891 года в Ставропольской губернии. - Ставрополь, 1949. - 89 с.

3. Чекменев С.А. Социально-экономическое развитие Ставрополья и Кубани. - Пятигорск, 1967. - 37 с.

\section{References}

1. GASK, F. 1279, op. 1, d. 1.

2. Krikunov, V. P. (1949). Krest'ianskaia reforma 1891 goda v Stavropol'skoi gubernii. p. 89. Stavropol'

3. Chekmenev, S. A. (1967). Sotsial'no-ekonomicheskoe razvitie Stavropol'ia i Kubani.p. 37. Piatigorsk

Новикова Ирина Евгеньевна - магистр ист. наук, учитель истории и обществознания МБОУ СОШ №6, Россия, Георгиевск.

Novikova Irina Yevgenyevna - Master of History, teacher of history and social science at School №6, Russia, Georgievsk. 